\title{
Formulation and Evaluation of Antimicrobial Herbal Soap
}

\author{
Dr.A.Seetha Devi*, D.V.Sivani, D.Anusha, G. Sarath, Syed Meraj Sultana \\ Hindu College of Pharmacy, Guntur-522002, Andhra Pradesh, India. \\ *Corresponding author's E-mail: seethagottipati@gmail.com
}

Received: 08-10-2021; Revised: 26-11-2021; Accepted: 05-12-2021; Published on: 20-12-2021.

\begin{abstract}
Bacterial skin infections are most common amongst people, requiring significant attention for treatment and also for maintaining healthy skin. Some herbal plant extracts and their oils were found to have antibacterial activity. The aim and objective of the present study are to formulate and evaluate anti-bacterial herbal soap using Azadirachta indica, Ocimum tenuiflorum oils. The antibacterial activity of the prepared formulations was tested using the agar well diffusion method against the organisms Pseudomonas aeruginosa, Staphylococcus aureus and, Escherichia coli and they exhibited a good anti-bacterial effect. The prepared formulations were evaluated for various physicochemical parameters for which good characteristics were observed. The easy availability of plants and their effectiveness helps manufacturers with cost-effective benefits and with less or no side effects.
\end{abstract}

Keywords: Herbal Soap, Azadirachta indica, Ocimum tenuiflorum, Cold process method, Agar well diffusion method.

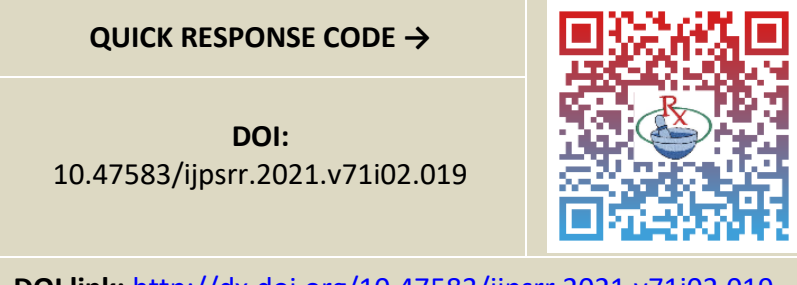

DOI link: http://dx.doi.org/10.47583/ijpsrr.2021.v71i02.019

\section{INTRODUCTION}

oap is a mixture of sodium salts of various naturally occurring fatty acids. If the fatty acid salt has potassium rather than sodium, a softer lather is the result. Soap is produced by saponification or basic hydrolysis reaction of a fat or oil. Most commercial soaps contain chemicals that can be harmful to the skin and using a natural herbal soap can be a good alternative. Herbal soaps are made using natural herbs and ingredients that are healthier and beneficial for the skin and are less likely to cause any damaging effect ${ }^{1}$. Some of the natural soap manufacturers also use aromatherapy and herbal treatments to offer the best skin treatment solution for your skin. Made of rare herbs and $100 \%$ natural ingredients, herbal soaps are found to be highly beneficial for the skin. The herbs infused in these soaps have therapeutic and healing characteristics that offer specific benefits to the skin, such as nourishment, strength, healing, and moisturizing. These soaps also contain super fatty oils, Vitamin E, Aloe, and essential oils that are allied to the goodness of skin and overall health ${ }^{2}$.

Herbal soaps are also effective in curing different skin complaints. These soaps also contain glycerine, which is generally not used in commercial soaps. Glycerine helps in retaining the moisture in the skin thereby making these soaps for dry skin conditions. Herbal soap preparations are medicines or drugs which contain anti-bacterial \& anti- fungal agents which mainly uses parts of plants such as like leaves, stem, roots \& fruits for treatment for an injury or disease or to achieve good health. These preparations possess anti-microbial properties and are administered topically and available to apply in various forms like creams, gels, soaps, solvent extracts, or ointment ${ }^{53}$. In the present study, Azadirachta indica and Ocimum tenuiflorum oils were used to prepare the anti-bacterial herbal soaps and their physicochemical characteristics were evaluated.

\section{MATERIALS AND METHODS}

Sodium hydroxide was procured from Qualigens Fine chemicals, Mumbai. Neem oil, Tulasi oil, and Coconut oil were procured from the local market. Glycerine, Propylene Glycol, and Sodium lauryl sulfate were procured from Thermo fisher scientific India Pvt Itd., Mumbai. Triethanolamine was procured from Loba Chemie Pvt Itd., Mumbai. The other entire chemicals used were of analytical grade.

\section{Procedure for Preparation of Anti-microbial Herbal Soap}

\section{Preparation of medicated soap}

\section{Cold process method}

Two herbal soap formulations (F1\&F2) were prepared by cold press method given in table no.1. Formulation F1 soap base was prepared by taking $72 \mathrm{ml}$ of coconut oil in $500 \mathrm{ml}$ of the beaker. It was placed on the water bath \& heated to $70{ }^{\circ} \mathrm{C}$. After that $29.5 \mathrm{gms}$ of sodium hydroxide was weighed and dissolved in $40 \mathrm{ml}$ of distilled water. Sodium hydroxide or Lye solution was heated to $70{ }^{\circ} \mathrm{C} \&$ added to coconut oil which was maintained at the same temperature. The mixture was stirred slowly and removed from the water bath after the mixture was thickened; $2 \mathrm{ml}$ of Neem oil, $2 \mathrm{ml}$ of Tulasi oil and $1 \mathrm{ml}$ of jasmine oil, and 15

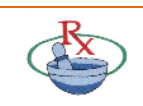


gm of SLS, and $0.2 \mathrm{ml}$ of amaranth solution were added to the above-thickened mixture. All the contents were stirred properly (vigorous stirring was avoided to reduce foam formation in the mixture) to get a uniform soap mixture. Finally, this soap mixture was poured into circular moulds having dimensions of $8.4 \mathrm{~cm}$ diameter. The moulds were kept aside for 3-4 days for the solidification of soap ${ }^{4}$.

Formulation F2 soap base was prepared by taking $1.6 \mathrm{gm}$ sodium hydroxide and dissolved in distilled water and the solution was heated to $70{ }^{\circ} \mathrm{C}$. In another beaker $18.75 \mathrm{ml}$ of Propylene glycol, $6.25 \mathrm{ml}$ of glycerine, $19 \mathrm{ml}$ of ethanol, and $15 \mathrm{gm}$ of SLS were taken into $250 \mathrm{ml}$ beaker on the hot plate with a stir bar and heated the mixture to $60^{\circ} \mathrm{C}$. Once this heat is attained $13.0 \mathrm{gm}$ of Stearic acid was added and heated to $68^{\circ} \mathrm{C}$ and slowly added the lye solution with stirring until the mixture becomes transparent. Further required quantity of herbal oils like $2 \mathrm{ml}$ of Neem oil, $2 \mathrm{ml}$ of Tulasi oil, and $0.2 \mathrm{ml}$ of amaranth solution were mixed to the above mixture, and volume was made up to $100 \mathrm{ml}$ by adding remaining distilled water. The solution was kept undisturbed for a 1 hour at $68^{\circ} \mathrm{C}$ and a few drops of essential oil ( $1 \mathrm{ml}$ of jasmine oil) was also added to impart aroma to the prepared soap and after 1 hour $5 \mathrm{ml}$ Triethanolamine (TEA) was added slowly and the soap solution was cooled to $62-64^{\circ} \mathrm{C}$ and finally, the soap mixture was poured into circular moulds having dimensions of $8.4 \mathrm{~cm}$ diameter. The moulds were kept aside for 3-4 days for the solidification of soap.

Table 1: Formulation of Anti-microbial Herbal Soap

\begin{tabular}{|l|l|c|c|l|}
\hline S. No & \multicolumn{1}{|c|}{ Ingredients } & Formulations $\mathbf{( 1 0 0 \mathrm { gm } )}$ & \multicolumn{1}{|}{ Uses } \\
\hline 1 & & F1 & F2 & \\
\hline 2 & Sodium hydroxide & $29.5 \mathrm{gm}$ & $1.6 \mathrm{gm}$ & Lye \\
\hline 3 & Stearic acid & -- & $13 \mathrm{gm}$ & Hardening agent \\
\hline 4 & Neem oil & $2 \mathrm{ml}$ & $2 \mathrm{ml}$ & Anti-bacterial agent \\
\hline 5 & Tulasi oil & $2 \mathrm{ml}$ & $2 \mathrm{ml}$ & Anti-bacterial \& Anti-fungal agent \\
\hline 6 & Coconut oil & $72 \mathrm{ml}$ & -- & Saponifying agent \\
\hline 7 & Glycerine & $1 \mathrm{ml}$ & $1 \mathrm{ml}$ & Perfume \\
\hline 8 & Propylene Glycol & -- & $6.25 \mathrm{ml}$ & Humectant \\
\hline 9 & Sodium lauryl sulfate & $15 \mathrm{gm}$ & $15 \mathrm{gm}$ & Surfactant \\
\hline 10 & Triethanolamine & -- & $5 \mathrm{ml}$ & pH Adjustifying agent \\
\hline 11 & Amaranth solution & $0.2 \mathrm{ml}$ & $0.2 \mathrm{ml}$ & Colouring agent \\
\hline 12 & Ethanol & -- & $19 \mathrm{ml}$ & Antimicrobial \\
\hline 13 & Distilled water & Q.s.100ml & Q.s $100 \mathrm{ml}$ & Vehicle \\
\hline
\end{tabular}

\section{Evaluation Tests}

Evaluation of physicochemical parameters of the prepared formulation, various physicochemical parameters which are mentioned below were performed to establish the quality of the prepared formulations.

1. Determination of Organoleptic Characteristics: Clarity and colour was checked by naked eyes against the white background, and the odour was smelled ${ }^{5}$.

2. Size and shape Determination: The soap diameter of the size of $8.4 \mathrm{~cm}$, with a thickness of $2.6 \mathrm{~cm}$, which is round-shaped, was chosen for the preparation of soap bars. This was chosen, as this size is ideal in regular usage to apply on the affected skin parts of the body ${ }^{6}$.

3. Thickness determination: The thickness was determined with the help of a screw gauge which is pre-calibrated. The thickness was measured, by observing the thickness at five different parts of the soap ${ }^{7}$.
4. Weight determination: The weight was determined by using a Digital weighing balance ${ }^{8}$.

5. Foam Height: $:^{23} 0.5 \mathrm{gm}$ of the sample of soap was taken and dispersed in $25 \mathrm{ml}$ of distilled water. Then, transferred it into $100 \mathrm{ml}$ measuring cylinder; the volume was made up to $50 \mathrm{ml}$ with water. 25 strokes were given and stand till aqueous volume was measured up to $50 \mathrm{ml}$ and measured the foam height, above the aqueous volume ${ }^{9}$.

6. Foam Retention: Prepared the $25 \mathrm{ml}$ of the $1 \%$ soap solution and transferred it into the $100 \mathrm{ml}$ measuring cylinder. Then the cylinder was shaken 10 times. The volume of foam was recorded at one minute for 4 to 5 minutes ${ }^{10}$.

7. pH TEST: The $\mathrm{pH}$ test was performed for all the formulations. Each formulation of soap solution was dissolved in $20 \mathrm{ml}$ of distilled water and tested for $\mathrm{pH}$ with the help of a digital $\mathrm{pH}$ meter. The measurement of $\mathrm{pH}$ of all the formulations was done in the previously calibrated $\mathrm{pH}$ meter ${ }^{11}$. 
8. Alcohol insoluble matter: $5 \mathrm{gm}$ of soap was taken in a conical flask and added $50 \mathrm{ml}$ warm ethanol and shaken vigorously to dissolve the soap. The solution was filtered through a tarred filter paper with $20 \mathrm{ml}$ of warm ethanol and dried at $105{ }^{\circ} \mathrm{C}$ for $1 \mathrm{hr}$. The weight of the dried paper with residue was taken ${ }^{12}$.

Formula: \% Alcohol insoluble matter $=\mathrm{Wt}$. of residue x100/wt. of sample

9. High-temperature stability: Liquid soap was allowed to stand at $50^{\circ} \mathrm{C}$ for 1 week. The stability of liquid soap was observed during this period. The sample which was homogenous and stable liquid after standing was indicated as stable and the sample in which the crystals were roughened and the sample in which precipitation was caused then liquid soap was said to be as unstable ${ }^{13}$.

10. Anti-microbial test: The prepared soap was subjected to antimicrobial screening by the agar well diffusion standard cup plate method. Organisms used were E. coli, S. aureus, and P. aeruginosa. One gram of soap was mixed with $5 \mathrm{ml}$ of sterile water ${ }^{14}$.

Evaluation of Prepared Herbal Soap Formulation for Antimicrobial Activity

The [agar -well diffusion] standard cup plate technique was used to determine the antimicrobial activity by using sabouraud's dextrose agar [Hi- media]. The melted media were seeded with the suspension of microorganisms and allowed to solidify. The formulations were aseptically transferred to the Hi-media in Petri-dish with the help of sterile forceps. The medicated soap was kept for incubation in an incubator at $30^{\circ} \mathrm{C}$ for 5-7 days $\mathrm{s}^{15}$. Observation: The assessment of antimicrobial activity was based on the measurement of the diameter of the zone of inhibition in $\mathrm{mm}$. The values were recorded and given in table no 3 .

\section{RESULTS AND DISCUSSIONS}

The evaluation of anti-microbial herbal soap was performed successfully and tabulated in table no.2. The prepared herbal soap was shown in figure 1 . The physicochemical parameters for herbal soap formulations F1 and F2 such as color, appearance, $\mathrm{pH}$ were determined. The formulations have a light pink color with an aromatic odor and had a good appearance as well as the $\mathrm{pH}$ was found to be in the range of 7.0-7.3. Healthy skin has a pH of 5.4 to 5.9 and the prepared formulations $\mathrm{pH}$ was found to be neutral in nature and doesn't cause any irritation or sensitization to the skin. Other parameters like foam height, foam retention were also performed and showed good results, the prepared soaps produced good lather i.e. $2.5-3.0 \mathrm{~cm}$ and retained on the skin for 3 minutes. Alcohol insoluble matter was also evaluated successfully which was found to be 15-18\%, indicates that the prepared soaps were free from non-soap ingredients and soft soaps were produced which improves the overall quality of the soap. The anti-microbial activities of herbal soaps were studied. The results obtained from the studies were shown photographically as well as in table no:
2. The zone of inhibition for F1 and F2 formulations were calculated. F2 formulation showed a maximum zone of inhibition than the F1 formulation. A significant result was obtained for F2 formulation against Pseudomonas aeruginosa, Staphylococcus aureus and Escherichia coli, which were found to be $15 \mathrm{~mm}, 18 \mathrm{~mm}$, and $16 \mathrm{~mm}$ respectively due to the synergistic effect produced by the incorporation of alcohol in the F2 formulation, which showed significant zone of inhibition and acts effectively against bacteria on the skin and can be used to treat acne and bacterial infections on the skin. F2 formulation was found to be the best formulation due to good quality of the soap with a neutral $\mathrm{pH}$, safe to use on the skin without any irritation to the skin and also it forms good lather and retains well on the skin. The prepared Soap had minimal matter insoluble in alcohol and the soap prepared was pure with minimal moisture content and with increased shelve life. The F2 formulation has high amounts of fatty acid (stearic acid) which imparts lubrication effect to the skin while washing, which was the basic criterion of good quality soap.

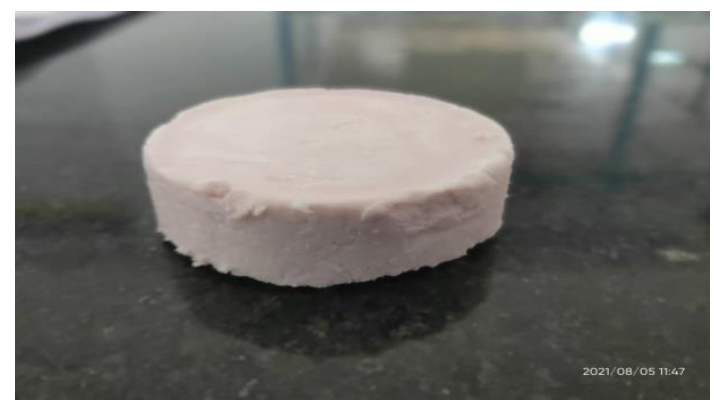

Figure 1: Prepared Anti-microbial Herbal soap

Table 2: Physicochemical Parameters of Herbal Soap Formulations

\begin{tabular}{|c|c|c|c|}
\hline S.no & Parameters & $\begin{array}{c}\text { Formulation } \\
\text { F1 }\end{array}$ & $\begin{array}{c}\text { Formulation } \\
\text { F2 }\end{array}$ \\
\hline 1. & Colour & Light Pink & Light Pink \\
\hline 2. & Odor & Aromatic & Aromatic \\
\hline 3. & Appearance & Good & Good \\
\hline 4. & Size & $\begin{array}{c}8.4 \mathrm{~cm} \times 2.6 \\
\mathrm{~cm}\end{array}$ & $\begin{array}{c}8.4 \mathrm{~cm} \times 2.6 \\
\mathrm{~cm}\end{array}$ \\
\hline 5. & Shape & Round & Round \\
\hline 6. & $\begin{array}{l}\text { Foam Height } \\
(\mathrm{cm})\end{array}$ & 2.5 & 3.0 \\
\hline 7. & $\begin{array}{l}\text { Foam Retention } \\
\text { (Min) }\end{array}$ & 3.0 & 3.0 \\
\hline 8. & $\mathrm{pH}$ & 7.3 & 7.0 \\
\hline 9. & $\begin{array}{l}\text { Alcohol } \\
\text { insoluble } \\
\text { matter (\%) }\end{array}$ & 18 & 15 \\
\hline 10. & $\begin{array}{l}\text { High- } \\
\text { temperature } \\
\text { stability }\end{array}$ & $\begin{array}{l}\text { Soap melts } \\
\text { above } 45^{\circ} \mathrm{C}\end{array}$ & $\begin{array}{l}\text { Soap melts } \\
\text { above } 50^{\circ} \mathrm{C}\end{array}$ \\
\hline
\end{tabular}


Table 3: Antimicrobial Test for Herbal Soaps

\begin{tabular}{|c|c|c|c|c|}
\hline S.no & $\begin{array}{c}\text { Formulation } \\
\text { code }\end{array}$ & \multicolumn{3}{|c|}{ Zone of inhibition (mm) } \\
\hline & & \multicolumn{3}{|c|}{ Microorganisms } \\
\hline 1 & P. & S. & E. \\
aeruginosa & aureus & coli \\
\hline 2 & F1 & 12 & 14 & 13 \\
\hline & F2 & 15 & 18 & 16 \\
\hline
\end{tabular}

Figure 2: Zone of Inhibition for F2 formulation

1. P. aeruginosa, 2. S. aureus, 3. E. coli

\section{SUMMARY AND CONCLUSION}

In the present work, antimicrobial herbal soaps were prepared, with suitable size and shape, thickness, weight, and with good foam producing ability. Herbal soaps of neem and tulsi were prepared for their anti-bacterial activity for the treatment of pimples, acne and scars. Two different formulations F1 and F2 were prepared by cold press method and the formulations were characterized for different evaluation parameters like clarity, color, and odor, size, and shape, thickness, weight, $\mathrm{pH}$ in which they exhibited satisfactory results. The herbal soap showed a good appearance with pink color and with a pleasant aromatic smell and showed good anti-bacterial properties. Based on the study it can be concluded that herbal products can be effectively formulated in the form of medicated herbal soaps by using cold process technique with excellent anti-bacterial properties.

Acknowledgments: The authors are thankful to the Hindu College of Pharmacy for providing the necessary facilities to carry out this research work.

\section{REFERENCES}

1. Grace X. F, Sowmya K. V, Darsika C, Polyherbal Hand Sanitizer Formulation and Evaluation, Indian Journal of Pharmacy and Pharmacology, 2015;2(2): 143-144.
2. Tortora G. J, Grabowski S. R. Principles of Anatomy and Physiology.10th edition, published by John Wiley and Sons; 2003, 140-143.

3. Sunhyo R, Peter I. S, Chang H. S, Hyeonsook C, Yoonkyung P, Colonization and Infection of the Skin by S. aureus Immune System Evasion and the Response to Cationic Antimicrobial Peptides, International Journal of Molecular Science, 2014;15(5):87538772.

4. Choudhari S, SutarM, Chavan M, Formulation Evaluation and Antibacterial Efficiency of herbal hand wash, Indo American Journal of Pharmaceutical Research, 2016; 6(4): 5202-2503.

5. Saad A. H, Gamil S. N, Kadhim R. B, Samour R, Formulation and Evaluation of Herbal Hand Wash from Matricariachamomilla Flowers Extracts, International Journal of Research in Ayurveda and Pharmacy 2011;2(6):1811-1813.

6. Ruckmani K, Krishnamoorthy R, Samuel S, Kumari H. L. J, Formulation of Herbal Bath Soap from Vitexnegundo Leaf Extract, Journal of chemical and pharmaceutical sciences,2014;13(2):95-6.

7. Sharma A, Yadav R, Guha V, Soni U. N, Patel J. R, Formulation and Evaluation of Herbal Hand Wash, World Journal of Pharmacy and Pharmaceutical Sciences, 2016; 5(3): 675-683.

8. Londhe J, Jagpat S. D, Doshi C, Formulations of Herbal Hand Wash with Potential Antibacterial Activity, International Journal of Research in Advent Technology, 2015: 21:11-12.

9. Rangari V. D, Pharmacognosy and phytochemistry,2nd edition reprint.career publication; Nashik; May 2012, 115.

10. Majekodunmi S. O, Essien A. A, Development and evaluation of antimicrobial herbal formulations containing the methanolic extract of Cassia alata for skin diseases, Journal of Coastal Life Medicine, 2014; 2(11): 872-875.

11. Kokate C. K, PurohitA. P, Gokhale. B, Pharmacognosy. 29th edition, published by Nirali Prakashan; Pune; 2009.

12. Ragnar. D, Pharmacognosy and phytochemistry. 2nd edition reprint. Volume 1st, published by career publication; Nashik; 2012, 115 .

13. Londhe J, Jagtap S. D, Doshi C, Jagade D, Formulations of Herbal Hand Wash with Potential Antibacterial Activity, International Journal of Research in Advent Technology, 2015;31: 11-14.

14. Moghadamtousi S. Z, Kadir H. A, Hassandarvish P, Tajik H, Abubakar S, Zandi K, A Review on Antibacterial, Antiviral and Antifungal Activity of Curcumin, BioMed Research International, 2014; 18:1-12.

15. Khadbadi S.S, Deore S.L, Bhaviskar B.A. Experimental phytopharmacognosy A Comprehensive Guide. 1st edition. Published by Nirali Prakashan; 2011.

Source of Support: Hindu College of Pharmacy.

Conflict of Interest: The author(s) declared no potential conflicts of interest with respect to the research, authorship, and/or publication of this article.

For any question relates to this article, please reach us at: editor@globalresearchonline.net

New manuscripts for publication can be submitted at: submit@globalresearchonline.net and submit_ijpsrr@rediffmail.com 